\title{
DO SIZE, DEBT, LIQUIDITY, CAPITAL STRUCTURE, AND CAPACITY AFFECT FINANCIAL PERFORMANCE IN U.S. LEGACY AND LOW-COST AIRLINE CARRIERS?
}

Bert J. Zarb, Embry-Riddle Aeronautical University, U.S.A.

dx.doi.org/10.18374/JIFE-20-1.5

\begin{abstract}
Ever since airline deregulation in the late seventies, airlines have been operating in a tough environment perpetuated by exogenous forces faced by no other industry. Oil price volatility, calamitous events, such as the terrorist attacks of September 11, bird flu, consumer preference, disposable income, the financial crises of 2008-2009, airline consolidations, and the emergence of new carriers have all played their part in creating a very challenging landscape through which airlines have to navigate on a day-to-day basis. This article addresses whether there exists a relationship between an airline's size, debt, liquidity, asset structure, and capacity utilization with its performance. Using associational inferential statistics together with an independent t-test, the results show that while, all these variables contribute to a usable model, only liquidity and capacity utilization are statistically significant. Furthermore, the results of this study show that there is no significant difference in performance between legacy and low-cost carriers.
\end{abstract}

Keywords: Size, debt, liquidity, capital structure, capacity, airline industry 